\title{
Homilia do dzieci - spojrzenie liturgisty
}

Problematyce homilii do dzieci Dyrektorium o mszach z udziałem dzieci poświęca jeden punkt, w którym zapisano: „we wszystkich mszach z udziałem dzieci ważne zadanie spełnia homilia, która wyjaśnia słowo Boże. Homilia skierowana do dzieci niekiedy będzie przechodzić w dialog z nimi, chyba, że lepiej jest, aby dzieci słuchały w milczeniu"2. Samo Dyrektorium było wyrazem troski Kościoła o eucharystyczną formację dzieci, a szczególnie o adaptację liturgii słowa do możliwości percepcyjnych najmłodszych uczestników liturgii.

Czasem odnosi się wrażenie, że ten istotny dokument, zawierający niezbędne wskazówki odnoszące się do formacji dzieci, by aktywnie i świadomie uczestniczyły w Eucharystii, został przez wielu duszpasterzy odczytany niedobrze albo wręcz wcale. A przecież w naszej polskiej rzeczywistości dokumentowi temu „Ruch Biblijny i Liturgiczny” poświęcił już w 1977

\footnotetext{
$1 \quad$ Ksiądz doktor habilitowany, profesor Uniwersytetu Opolskiego. Prezbiter diecezji opolskiej, dyrektor Instytutu Liturgii, Muzyki i Sztuki Sakralnej na Wydziale Teologicznym Uniwersytetu Opolskiego. Zainteresowania: historia liturgii na Śląsku, posoborowa reforma liturgii, dzieje kultu świętych oraz współczesne rozumienie obrzędu, kultu i liturgii (erwinmateja@wp.pl).

2 Kongregacja do spraw Kultu Bożego, dyrektorium o mszach świętych z udziałem dzieci Pueros Baptizatos, 48, http://www.kkbids.episkopat.pl [dalej: DMD].
} 
roku specjalny, podwójny numer, publikując treść Dyrektorium oraz związane z nim artykuły. Autor jednego z nich podjął problem zastosowania środków audiowizualnych do udziału dzieci w mszy świętej3. Przypomniał numery 35 i 36 Dyrektorium. W pierwszym z nich zauważa się, iż w liturgii mamy cały szereg elementów wizualnych, które są związane z rokiem liturgicznym. Fakt ten jednak nie oznacza, że nie można wprowadzać nowych. Wręcz przeciwnie; ponieważ liturgia nigdy nie może wyglądać jak rzecz sucha i należąca wyłącznie do sfery myśli, należy korzystać z takich elementów wizualnych, które pozwoliłyby dzieciom uchwycić wzrokiem wielkie dzieła Boże. Zapewne ta argumentacja pozwala też na posługiwanie się takimi elementami w samej homilii. W numerze 36 czytamy bowiem, że „tematyka Ewangelii podjęta w homilii może być przybliżona poprzez wykorzystanie obrazów przygotowanych przez dzieci”. Życie pokazało, iż duszpasterze dość szeroko zinterpretowali te słowa i często używają w homiliach przeźroczy, rekwizytów, kukiełek, a nawet żywych aktorów, uważając, że nie jest nadużywaniem przesłania Dyrektorium, gdy przygotuje się z dziećmi inscenizację biblijnego wydarzenia przedstawionego w czytanym fragmencie Ewangelii. Interesujący nas dokument daje z całą pewnością duże możliwości, szczególnie pod względem adaptacji liturgii słowa do percepcyji dzieci.

Dyrektorium przypomina też na początku, jak ważna jest formacja liturgiczna, a przede wszystkim eucharystyczna, która powinna przebiegać wraz z pełnym wychowaniem chrześcijańskim i humanistycznym ${ }^{4}$. Ważną rolę w tym procesie odgrywa sama postawa kapłana, który celebruje mszę z dziećmi. Nie

3 J. Grygotowicz, Zastosowanie środków audiowizualnych do udziału dzieci w mszy św., „Ruch Biblijny i Liturgiczny” 2-3 (1977), s. 152-154.

4 DMD 8. 
może on stwarzać dystansu. W zbliżeniu się do uczestników Eucharystii zawsze pomaga fakt, że ksiądz jest przez dzieci lubiany, bo one czują, iż swoją postawą życzliwości i zauważenia każdego dziecka pokazuje, że mu na nich zależy. Dlatego też język, jakim posługuje się ksiądz, powinien być zrozumiały dla odbiorców, bez abstrakcyjnych pojęć, ale także bez infantylizowania. Dzieci muszą czuć, że homilia jest adresowana do nich. Niedoścignionym nauczycielem takiego przepowiadania jest sam Jezus Chrystus, który sięgał do przypowieści, metafor i obrazów wziętych z życia, by wyrazić prawdy o Królestwie Bożym.

Skoro Ewangelie pokazują nam Mistrza z Nazaretu, który umiał zaciekawić swoich słuchaczy tym, co mówił, to płynie z tego prosty wniosek, że dzisiejszy homilista mówiący do dzieci też musi wzbudzić zainteresowanie słuchaczy. Musi więc podejmować zagadnienia, którymi żyją dzieci, i dobrze jest, jeśli pokaże, że zwyczajne sprawy słuchaczy są mu dobrze znane. Nie oznacza to jednak, że głosiciel homilii ma się dopasowywać do dzieci i spełniać ich oczekiwania. Rodzi się wtedy niebezpieczeństwo, że będzie on głosił to, czego chcą dzieci, a nie to, co chce przekazać im Bóg. Występuje tu bowiem pokusa, by podejmować jedynie chwytliwe tematy, a inne zbywać milczeniem.

Dziecko jest słuchaczem o ograniczonej możliwości koncentracji, dlatego ważny jest też czas trwania homilii. Inaczej jednak wygląda sprawa, gdy chodzi o cotygodniową „mszę szkolną", a inaczej, gdy dzieci biorą udział w rekolekcjach, bo wtedy homilia jest z reguły dłuższa. To samo odnosi się do homilii towarzyszących szczególnie uroczystym chwilom, na przykład Pierwszej Komunii Świętej.

Każda okoliczność domaga się tego, by dzieci pod wpływem wysłuchanej homilii stały się radośniejsze i przekonane, 
że życie chrześcijańskie może być piękne, że warto żyć tak, jak uczy Chrystus. Dlatego nawet jeżeli duszpasterz musi poruszyć sprawy przykre, upomnieć, to przez jego słowa nie ma przebijać chęć karania, ale troska o dobro dzieci. Poza tym upomnień nie może być za dużo, bo dobry wychowawca wie, że więcej daje życzliwa zachęta niż ciągłe ruganie. Stale trzeba pamiętać o tym, że dzieci mają prawo, tak samo jak dorośli parafianie, czuć się na liturgii dobrze. Kościoły powinny być dla dzieci miejscami, do których te przychodzą z radością i wiedzą, że nie robią tego tylko z obowiązku. Wpływ na to ma w dużym stopniu słowo homilisty i sposób, w jaki je przekaże dzieciom.

Autor tych słów brał przed laty udział w uroczystości Pierwszej Komunii Świętej w Niemczech. Złamano tam wtedy wiele liturgicznych zasad, również te dotyczące homilii dla dzieci. Po odczytaniu Ewangelii do ambony podszedł mało uroczyście ubrany pan, który - jak się można było z jego słów dowiedzieć - należał do zespołu przygotowującego dzieci do Pierwszej Komunii Świętej. Cała „homilia” była opowiadaniem o tym, jak to dzieci przygotowywały świece pierwszokominijne, które stały na ołtarzu.

W Internecie można zobaczyć filmy będące polskimi przykładami wygłaszanych do dzieci homilii. Niestety są to w zdecydowanej większości homilie wygłaszane w czasie mszy rekolekcyjnych. Prawie we wszystkich oglądanych sytuacjach głosiciele homilii wybierali metodę dialogowaną. Można było zauważyć, że o wiele ciekawszą, wciągającą formą przepowiadania była ta, którą wygłaszali duszpasterze znający słuchaczy. Wtedy w dialogu pojawiały się imienne zaproszenia konkretnego dziecka do udzielenia odpowiedzi na pytanie księdza. O wiele trudniejszą sytuację mieli księża rekolekcjoniści, którzy dzieci nie znali. Dla niektórych jednak nie był to problem, bowiem ich doświadczenie w dialogowaniu z dziećmi pokazywało, że wiedzieli, 
co to znaczy używać prostego języka, poprawnie formułować pytania i konsekwentnie trzymać się tematu. Oczywiście duże znaczenie miał sam fakt, że dzieci w danej parafii były już przyzwyczajone do dialogowanej wersji homilii. W bardzo trudnej sytuacji jest bowiem ksiądz zaproszony na przykład z rekolekcjami do parafii, w której duszpasterz głosi do dzieci homilie od ambony w formie monologu. Dla takich dzieci głosiciel homilii próbujący z nimi rozmawiać jest zjawiskiem tak nowym, że czasem niemożliwym do zaakceptowania.

Osobnym problemem, który może budzić pewne wątpliwości, jest paleta pomocy używanych przez homilistę w celu zobrazowania poruszanego problemu. Od lat „Gość Niedzielny” przygotowuje dla duszpasterzy na msze roratnie nie tylko pomoce dla księdza, ale też materiały będące swoistą ilustracją do tematu homilii, a które każdego dnia są przez dzieci zawieszane na planszy w kościele i w małej wersji zabierane do domu. Te formy wizualizacji proklamowanych treści są dobrze odbierane nie tylko przez dzieci, ale też przez innych uczestników liturgii. Zdarzają się jednak sytuacje, kiedy homilista używa takich rekwizytów, które wręcz szokują uczestników liturgii albo wywołują histeryczny śmiech dzieci, po którym trudno nad nimi zapanować. Wydaje się, że w tym względzie wskazany jest swoistego rodzaju rozsądny umiar w doborze rekwizytów oraz w samym postępowaniu z nimi. Ksiądz rozbijający przed ołtarzem szklany rekwizyt i pojawiający się za chwilę ludzie sprzątający potłuczone niebezpieczne elementy tak koncentrują uwagę dzieci na tych zabiegach, że mowy nie ma o skupieniu ich uwagi na podjętym w homilii temacie.

Jeszcze na jedną rzecz warto zwrócić uwagę - nie zawsze duszpasterze stosują zalecenie zawarte w 54 numerze Dyrektorium. Czytamy tam, że „we Mszy z udziałem dzieci duże znaczenie ma pouczenie przed końcowym błogosławieństwem, 
ponieważ dzieci przed rozesłaniem potrzebują pewnego powtórzenia i zastosowania tego, co słyszały"s. Dodajmy, że chodzi tu o to, co usłyszały w homilii. Praktyka obserwowana w naszych parafiach pokazuje, że niestety nie zawsze duszpasterze wracaja przed rozesłaniem dzieci do przypomnienia im problemu, któremu była poświęcona homilia. Warto więc upowszechnić zalecenie Dyrektorium.

\section{Bibliografia}

Grygotowicz J., Zastosowanie środków audiowizualnych do udziału dzieci w mszy św., „Ruch Biblijny i Liturgiczny” 2-3 (1977), S. $152-154$.

Święta Kongregacja Kultu Bożego, Dyrektorium o Mszach św. Z udziałem dzieci, „Ruch Biblijny i Liturgiczny” 2-3 (1977), S. $71-85$.

5 DMD 54. 